\title{
An Assessment of English Language Influence on Anglophone
}

\section{Countries' Cultures}

\author{
Bello Yekeen ${ }^{1 *}$ \\ ${ }^{1}$ Department of English Language and Literature, Nile University of Nigerian, Abuja, Nigeria \\ *Bello, Yekeen, E-mail: belight1010@mail.com
}

Received: March 21, 2017

Accepted: March 31, 2017

Online Published: April 5, 2017

doi:10.22158/jecs.v1n1p1

URL: http://dx.doi.org/10.22158/jecs.v1n1p1

\begin{abstract}
The focus of this paper is to assess the influence of English language on Anglophone countries'cultures. The advent of missionaries' activities in the Anglophone countries through the medium of English language vis-à-vis its power and influence were highlighted to signify that the power and influence exerted by this language (English) over shadowed the African traditional beliefs such as in religion, education, marriage system, among others. A 10 item researcher-designed questionnaire based on 4Likert scale type of Strongly Agree, Agree, Disagree and Strongly Disagree was dispensed on 180 respondents from three geo-political zones of Nigeria. However, only 176 respondents made their questionnaire available that was computed for this study. The instrument was revalidated thus producing a reliability index of 0.61 . The finding revealed that highest percentage of the respondents strongly agreed that the Englishman's language has greatly influenced African cultures, especially that of Nigeria both positively and negatively. As a result of this, it was concluded that of all the heritages left behind in the British colonies by the British colonial overlords, probably, none is more important than the English language, and that is why it is indeed very likely that for some time to come, English will remain a vital access to global advances which is very essential for gaining access to science and technology, and that it is possible that the Anglophone countries could grind to a halt should the use of English language be outlawed for say five minutes. Based on the findings and the conclusion, it is therefore recommended that Africans, especially Nigeria cannot be an island to itself, and if it must have any global outlook it must embrace foreign influence and culture so that Africans as a whole and indeed Nigerians would fit into any global condition regardless of their cultural background.
\end{abstract}

\section{Keywords}

English language, Anglophone countries' cultures and traditional beliefs 


\section{Introduction}

The term culture is the total embodiment of the norms, values, customs and tradition of any group of people. Oderinde (2009) asserts that culture includes the method which the people use in producing food and other basic needs of the people, the rules and regulations that govern people's behaviours in a society such as the belief, relationships, moral principles governing their behaviour and the whole body of knowledge and technology of people. This implies that every human society has culture that exists in one form or the other. This also means that every African community has its own form of culture upon which the existence of its people is based (Oderinde, 2009). But except for a few local variations in some cases, the cultural traits that exist in African communities are almost identical to one another based on the two main aspects of culture; they are the material and non-material aspects of culture. The material culture consists of things which people have learned to make use of to satisfy their basic needs, the art and industry of the society such as bridges, bows and arrows, sun hats, among other things, while the non-material culture consists of what we cannot see physically but are learned from generation to generation through elders in the society. They include language, morals, religion, values, as well as technology of people, their music, dance, folklore, African beliefs, drumming, dressing, dietary patterns as well as other forms of traditional life, among several others (Odediran, 2009).

Like any other culture, African culture is a very complex one. The complexity lies in the aspects which it exhibits.

\section{Background Literature of the Study}

\subsection{Indigenous Economy}

Fafunwa (2006) posits that the pillars of African culture are seven and these are physical training, intellectual training, respect for elders and people in authority, vocational, social and emotional training of the young, including indigenous economy. The life wire of Africans was purely based on some activities such as farming (agriculture), craftwork and trading. The agricultural practice (majorly subsistence farming) is, however, predominant and it was carried out by the use of traditional tools such as hoes, cutlasses and axes. It is a labour-intensive occupation which demanded a large work force. Because of the utilitarian value of its produce as both food (subsistence) and cash crops, it, agriculture, remained the bedrock of the African economy at least up to the immediate period after independence of many African states. Similarly, craftwork such as pottery, tying and dying, weaving, spinning, blacksmithing, soap making, basketry, sculpturing, among other arts were done in many African communities. Indeed, rarely could one find any community without one craft or another. This has therefore accounted for the African indigenous technology which through ages had met the economic needs of the people.

In another development buying and selling of the agricultural produce and craftworks formed the basis of the trading activities in Africa, which was traditionally based on trade by barter. This means that all commercial activities were carried out by the exchange of produce for produce, but later developed into 
the use of cowries as a medium of exchange. This was like the money in currencies we use today in our day to day commercial activities. Fafunwa submits further that when the core values of African culture was religiously observed, everything went on well in the society. But with the introduction of foreign cultures and civilization, everything changed.

\subsection{Traditional Beliefs}

Meduewesi (2000) posits that prominent among vital roles being played by culture in a society are that culture guides the behaviour of the members of the society through traditional religious belief by serving as an agent of social control and molding of personalities in the society. This is done through the African traditional belief system as a notable aspect of her culture. The belief system took sustenance in the African Traditional Religion (ATR). The ATR centred on polytheism (the worshipping of gods and goddesses). In effect, the ATR is dominated by the idea of pantheistic divinities but still with the inherent belief in the existence of God Almighty as the Supreme Being (Omoniyi, 2004).

The characteristic of ATR is based on African philosophy which looks at Africans belief as being represented by a pyramid:

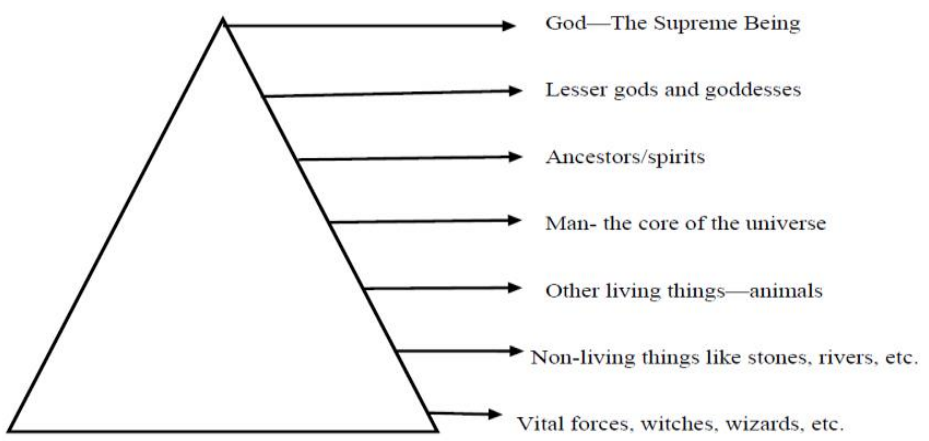

Figure 1. Pyramidal Position of Africans' Belief System

The above diagram shows the ATR belief that God, the Supreme Being is at the very top who is really not reachable except through intermediaries. This informed the Africans the worship of deities such as "ogun" the god of iron; "oya" the goddess of river; among others. Similarly, the lesser gods and goddesses were approached through the ancestors or, and the spirits. Viewing man as the core of the universe indicates others below the pyramid as lower entities which also got to the Supreme Being through him (man). These deities have their designated places and mode of worship (shrines) as well as festivals which were, and are still being celebrated from time to time by the African communities (Omoniyi, 2004). But with the coming of both the Western and the Eastern cultures, our traditional values are thrown away while foreign religions became vogue. In the light of this, Meduewesi (2000) and Oderinde et al. (2012) argue that there is then no wonder why our youths and the generality of the society lost their societal values and morals, thus giving rise to thuggery, cultism, drug and human trafficking, kidnapping and other such vices have pervaded African continent. 


\subsection{Traditional Education}

Before the advent or introduction of Eastern (Quranic) and Western educations, Africa had had its own educational system. The African education which is as old as the African communities had often been differently tagged "traditional" or informal education. It is so regarded because it did not require any special place or arrangement to thrive. The education was inherent in the culture of the African people and imparted to the youths by the elders and the communities at large. As such, the African traditional education naturally ensured strict disciplines in the way of respect for elders and strict adherence at all superstitious, taboos and the norms of the society. In the contrary, Oderinde (2009) posits that the abandonment of African's tradition almost costs Nigerians their languages in that an average Nigerian can hardly communicate without bringing in some elements of English language into that communication. It also paved way for Nigerians and the youths by wearing scanty, too tight, skinny and semi-naked dresses.

\subsection{Marriage System}

The system of marriage in African societies was polygamistic in nature which means that a man was, and is still allowed to marry more than one wife, and it was then regarded as a taboo for unmarried people to have sex in the traditional African society. It was not known that a lady became pregnant while she was yet unmarried (a lady must be "Virgo intacta"), until her wedding is concluded (Oderinde et al., 2012). Owing to the rich landscape and predominant agricultural practice by Africans which demanded for a great labour force support, encouraged Africans to customarily marry as many wives as possible for more procreation of children who would be used to mostly assist the African farming system of their respective families. In fact, it was then believed that a family's wealth depended on the number of wives and children a family had. To some extent polygamy practice remains part and parcel of the culture of African people.

\subsection{Traditional Authority}

Power and authority in African communities resided in the elders and traditional rulers (Obas, Obis, Emirs, and Bales). These elders especially the title holders jointly and severally constituted traditional authority and wielded considerable political and judicial powers. They had the power of appointment and dismissal of the officers that work under them. They sat in judgment over land despite, theft cases, divorce and adultery, among others. On most matters, their words were seen as laws and as such, their decisions were accepted as final, thus, making them capable of maintaining law and order in their various domains. While lending credence to the above, Adalumo A. J. and Adalumo C. (2016) affirm that respect for elders and constituted authorities was known to be much valued in the traditional African society especially Nigerian. The children had to prostrate (for boys) or kneel down (for girls) while greeting their elders, these aided peaceful co-existence among the Africans based on communalism and common respect. This is a form of living together in brotherhood which made it possible to do and share things in common with common interest. This, no double fostered unity, peace and communal spirit among the different communities in Africa. But in the contrary these days young 
people shake hands with elders, they find it convenient to sit in public buses while elders are standing, live in secluded areas characterised by "me and my wife and children alone life style", among many other disrespectful attitudes.

\subsection{External Influence}

External influences relate to the intruding factors which are outside a particulate culture and, therefore, regarded as foreign to it. It is generally believed that cultural differences are bound to happen where two or more geo-political entities are involved. In this regard, the advent of such things like Islam from the Middle Eastern part of the world, Christianity from Europe and America, among others, brought a wide gap between the African culture and the cultures of the intruders.

Islam for instance, is generally noted to be a foreign religion in Africa. It is said to be the region of the Arabs and was introduced to the continent from the Middle Eastern part of the world around 7th country A.D. Its presence was first noticed in North Africa in about 622 A.D. from where it spread gradually to other parts of the continent (Africa). Indeed, after the early19th century when different jihads (Muslim holy wars) were prosecuted, Islam became popular in many African communities, and as a result, it exerted a considerable influence on many aspects of African culture. Similarly, Christianity, like Islam is an alien religion in Africa. It was introduced to the African continent by the White Missionaries from the Western part of the world (Europe and America). The Portuguese's Missionaries took the lead, and in no distance time were followed by other missionaries from countries like Britain, Holland, Spain, Germany, Belgium, France and America. By the 15th country, the religion had been known in some parts of the continent. The faith gained strength to the extent that by the end of the 19th century through the beginning of the 20th century, the religion had been able to spread among many African communities, thus the religion, (English by implication) gave rise to many changes in African culture.

Western education came in the course of the Christian missionary activities in Africa. This is as a result of the fact that along-side the efforts to Christianise Africans was also to educate them (Africans). Thus, the missionaries established schools (Mission and Sunday Schools, Kindergarten, etc.) which were modeled on Western values. The basic objective of the education was to groom African adjuncts that could support the Missionaries in such positions as the interpreters, pastors and catechists. That was why the emphasis of the education whose seal was standard six, was basically on "3Rs" namely Reading, (W)riting and Religion. Although, the Western education also taught moral values, its general setting based on class-room work, teaching and learning in English language, examination, etc. were certainly anti-ethical to the traditional culture of the African communities (Oderinde et al., 2012).

\subsection{European Colonialism Influence}

Colonization means the condition of domination of a community over another community. In the case of Africa, European colonialism is the establishment of European rule in the African continent. In the light of this, Europeans were able to control the destiny of Africa and Africans. This control, a symbol of the aftermath of the scramble for and partition of Africa made European nations like Britain, 
Germany, France, Portugal, Belgium and Spain to share and colonize the African continent.

The first major influence of the European colonialism on Africa was the distortion in the structure of traditional authority. This is due to the fact that most African rulers lost their authority either directly (like the Francophone countries) to the colonial masters or indirectly (like the Anglophone countries) to their African subordinates who were usually the favourites of the colonial masters but who in most cases had no legitimate right to authority. To legitimise the presence of the colonial masters, they soon realised that communication with the people of Africa was a major serious problem. Since communication was seen as an indispensable feature of human existence, the colonial overlords made various attempts to communicate with the Africans especially the rulers, and the mixture of colonial varieties of English and the various indigenous languages gave rise to what is known today as pidgin (Bello, 2011).

The advent of the colonial masters and their English-speaking/French-speaking missionaries in large numbers to the African continent during this period brought up the question of a language to be adopted for communication between the indigenous population and their colonial masters. This created opportunities for the British overlords to introduce indirect system of administration via the use of the traditional rulers which made it possible for the Africans in this part of the continent to retain their language and some cultural aspects of their life (adulterated culture), while their French colonial counterparts adopted direct rule system which negatively made Africans in this part of the continent lost every aspect of their language and culture to their masters.

However, English, the language of the British colonial masters did not immediately replace the indigenous language for two reasons. First, the Missionaries had among them the "Saro expatriates" from Sierra Leone who were versed in both English and indigenous languages and who could therefore serve as interpreters for their English-speaking colleagues and the teaming indigenous population. Secondly, many of the missionaries began to learn the local languages in order to reach out to the people and spread Christianity. This was in compliance with the guiding principles of the missionary programme.

These guiding principles of the missionary activities in West Africa (Anglophone countries), especially Nigeria, the introduction of literacy, the training of missionary agents and the acquisition and the interpretation of the Bible meant essentially that the missionary must have to develop and learn the indigenous languages of the people or train local people in English. In either way, the Bible must be read and understood by the people, as such superimposing the Bible on these indigenous people. In line with this, the demand by the indigenous people for English language was decisive. English language then started to flourish due to the fact that the missionaries kept training these indigenous people in schools and mission homes through the medium of English, which soon because the language of communication, thus beginning what was known as using English as lingua franca. The British government then found out, and were impressed by the activities of the missionaries in the British controlled states generally and as such stepped in to propound guidelines for the organisation of 
education and to emphasise learning of English in schools.

To further strength the presence of British in her colonies, Bello (2011) asserts that the colonial government started putting Africa colonies on the path towards modernisation. The modernisation programme brought developments in the areas of transportation, communications, extensive agricultural and industrial schemes and expansion of educational system. The modernisation process was done through the medium of English, the language of the colonial masters, thus virtually destroying our traditional culture for all aspects of the modernisation tailored towards the appreciation of the European culture. Hitherto, the English language became (and even up to date) the language for official matters, thus giving it a high priority, as it has to be used first before any indigenous language if they are to be used at all; the language's supremacy is the fact that the national constitutions of all British colonies are written and interpreted in English language; the English language remains the language with which these colonies conduct their businesses, it is used as the nation's official language in government, in drafting constitution, decrees and edits; it is also used in judiciary for writing proceedings, judgments and keeping records.

In secondary schools, tertiary institutions or at the university level, instructions in indigenous language courses in Hausa, Igbo, Yoruba, Twi, Gan, Nfante, Krobo, Swahili, among other Anglophone indigenous languages are taught in the medium of English language. Equally, the language is used in industries and also for large scale businesses, for awarding contracts and advertisements. The language is also used for communicating in the print media as well as in the mass media; it also aids communication across borders; it is the language of diplomacy as well as that of inter-ethnic communication; people who share the same ethnic background favours the use of English on formal occasions such as send off parties, staff meetings, taking minutes, inaugural ceremonies, among others (Bello, 2006).

In addition this modernisation process (English language by implication), is why issues relating to such things as marriage, belief system, festivals, dress, commerce, currency and banking among a host of others are treated within the context of European culture.

\section{Purpose of the Study}

The purpose of this study is to assess the influence of English language on the cultures of Anglophone countries with a view to ascertaining whether the influence is positive or negative or ambivalent.

\subsection{Research Question}

The following one research question with 10 item questionnaire was generated for this study:

1) What is the influence of English language on the Anglophone countries' cultural practice?

\section{Methodology}

This study adopts a descriptive research design. The sample population consists of respondents from all the six geo-political zones of Nigeria as one of the Anglophone countries in Africa. Random sampling 
method was used to select 3 zones of the East, North and West from the six geo-political zones from where 60 respondents from each of the three zones were randomly selected giving a total of 180 as respondents from institutions of learning and traditional institutions. The instrument for data collection was a 10 item researcher-designed questionnaire. Internal consistency and validity of the questionnaire were established using Cronbach alpha giving 0.66. The instrument was revalidated and a reliability index of 0.61 was attained. Employing 4-Likert scale type of Strongly Agree (SA), Agree (A), Disagree (D) and Strongly Disagree (SD), the only research question was analysed using Frequency Count and Percentage Distribution. Out of the 180 respondents sampled for the study only 176 respondents' questionnaire were received and computed for this study.

\subsection{Data Analysis and Result}

Research Question: What is the Influence of English Language on the Anglophone Countries' Cultural Practice?

Table 1. Frequency Count and Percentage Distribution of the Influence of English Language on Anglophone Countries' Cultural Practice

\begin{tabular}{|c|c|c|c|c|c|c|c|c|c|}
\hline $\mathrm{S} / \mathrm{N}$ & Questionnaire items & SA & $\%$ & A & $\%$ & $\mathrm{D}$ & $\%$ & SD & $\%$ \\
\hline 1 & $\begin{array}{l}\text { Many Nigerians prefer European diets, dresses, } \\
\text { dressing, music, etc. to their native ones. }\end{array}$ & 160 & 90.91 & 10 & 5.68 & 6 & 3.41 & 0 & 0 \\
\hline 2 & $\begin{array}{l}\text { The advent of English men and their language } \\
\text { made us to lose our cultural values. }\end{array}$ & 166 & 94.38 & 3 & 1.70 & 0 & 0 & 7 & 3.98 \\
\hline 3 & $\begin{array}{l}\text { The Englishman's culture discouraged us from our } \\
\text { traditional polygamous system of marriage. }\end{array}$ & 170 & 96.59 & 5 & 2.84 & 0 & 0 & 1 & 0.57 \\
\hline 4 & $\begin{array}{l}\text { The Englishman's culture now makes us to live in } \\
\text { secluded houses (referred to as flats and } \\
\text { bungalows) away from other members of our clan. }\end{array}$ & 170 & 96.59 & 0 & 0 & 0 & 0 & 6 & 3.41 \\
\hline 5 & $\begin{array}{l}\text { African traditional religions have been taken over } \\
\text { by foreign religions (Islam and Christianity). }\end{array}$ & 111 & 63.07 & 57 & 32.39 & 8 & 4.55 & 0 & 0 \\
\hline 6 & $\begin{array}{l}\text { European culture has brought civilisations such as } \\
\text { education, orthodox medication, electricity, etc. }\end{array}$ & 158 & 89.77 & 18 & 10.23 & 0 & 0 & 0 & 0 \\
\hline 7 & $\begin{array}{l}\text { Not much authority is accorded our traditional } \\
\text { rulers (Emirs, Obas and Obis) as dictated by the } \\
\text { European culture. }\end{array}$ & 123 & 69.89 & 41 & 23.30 & 9 & 5.11 & 3 & 1.70 \\
\hline 8 & $\begin{array}{l}\text { We almost lost our language to European language } \\
\text { because we hardly converse for say five minutes } \\
\text { without bringing in the whiteman's language into } \\
\text { it. }\end{array}$ & 174 & 98.86 & 0 & 0 & 2 & 1.14 & 0 & 0 \\
\hline 9 & $\begin{array}{l}\text { It is not only the culture of the Western world that } \\
\text { influences us, but that of the Eastern world } \\
\text { (Arabian) too. }\end{array}$ & 136 & 77.27 & 40 & 22.72 & 0 & 0 & 0 & 0 \\
\hline 10 & $\begin{array}{l}\text { Nonetheless, science and technology which every } \\
\text { nation today has embraced for positive things is } \\
\text { brought about by the European culture. }\end{array}$ & 174 & 98.86 & 2 & 1.14 & 0 & 0 & 0 & 0 \\
\hline
\end{tabular}

\section{Discussion}

The results of the study show that 174 respondents representing $98.86 \%$ strongly agreed that 
Anglophone West African countries and indeed Nigeria almost lost her language identity to the European language (English language especially) because Nigerians of all tribes hardly speak for say five minutes without bringing in elements of the Whiteman's language into it. This finding is in conformity with the assertion of Oderinde (2009) that says that abandonment of the African tradition almost costs Nigerians their languages in that an average Nigerian hardly communicate without bringing in some elements of English language. It is also in line with the submission of Bello (2011) that since communication was seen as an indispensable feature of human existence, the colonial masters made frantic attempt on arrival to communicate with the Africans especially with the African rulers. The advent of colonial varieties of English coming in contact with the various indigenous languages gave rise to what we have today as pidgin English which is now rampant everywhere in Africa particularly Nigeria at the expense of their native languages. Here, only 2 respondents representing $1.14 \%$ disagreed with the notion.

However, 174 respondents representing $98.86 \%$ strongly agreed as well as 2 respondents representing $1.14 \%$ agreed that science and technology, the bedrock for national development was brought about by the European culture. This finding is in agreement with the assertion of Bello (2011) that the British, in order to strengthen their presence in her colonies, started putting the colonies on the path towards modernisation which brought about transportation system, education, communication, extensive agricultural practice and industrial scheme.

Next to the above are 170 respondents representing $96.59 \%$ who strongly agreed as well as 5 respondents representing 2.84\% who agreed that the Englishman's culture discouraged Africans from the traditional polygamous system of marriage. The finding connotes with the submission of Oderinde et al. (2012) that say because of the rich landscape and predominant agricultural practice by Africans which demanded for a great labour work force support, encouraged Africans to customarily marry as many wives as possible for more procreation, the children who would be used to mostly assist the African farming system of their respective families. It was believed that a family's wealth depended on the number of wives and children a family had. Here, only 1 respondent representing $0.57 \%$ strongly disagreed with the finding. Closely at the heel to the above are 170 respondents with a percentage of 96.59\% strongly agreed that the Englishman's culture has made Africans to live in secluded houses (referred as flat and bungalows) away from other members of their clans. This finding is in line with the assertion of Adalumo A. J. and Adalumo C. (2016) who agree that the traditional African system was a form of living together in brotherhood which made it possible to do and share things in common with common interest. This, no double fosters unity, peace and communal spirit among the different communities in Africa. Only 6 respondents standing for $3.41 \%$ had strong disagreement with the finding.

Next to the above are 166 respondents standing for $94.38 \%$ strongly agreed as well as 3 respondents representing 1.70\% agreed respectively that the advent of Englishmen and their language made Africans to lose their cultural values, this is in agreement with the findings of Meduewesi (2000) and 
Oderinde et al. (2012) who argue that the coming of Englishmen and their language made Africans lose their cultural values, there is then no wonder why our youths and the generality of the society lost their societal values and morals, thus giving rise to thuggery, cultism, drug and human trafficking, kidnapping and other such vices have pervaded African continent. Only 7 respondents representing $3.98 \%$ strongly disagreed to the finding which falls in line with the finding of Oderinde et al. (2012) that although the Western education also taught moral values, its general setting based on class-room work, teaching and learning in English language, examination, etc. were certainly anti-ethical to the traditional cultures of the African communities.

Coming next in rank to the above are 160 respondents representing $90.91 \%$ of strongly agreed and 10 respondents standing for 5.68\% agreed respectively that many Nigerians prefer the European diets, dress, dressing, music etc. to their native ones. The finding supports the study of Oderinde et al. (2012) who submit that today many Nigerians prefer the European diet, dressing, language, music and dance to their native ones, while only 6 respondents standing for $5.68 \%$ disagreed. Closely next to the above are 158 respondents representing $89.77 \%$ and 18 respondents representing $10.23 \%$ who respectively strongly agreed and agreed that Europeans' culture has bought civilisations such as education, hospital, rule of law among several others. This finding is in agreement with the assertion of Bello (2011) that the British, in order to strengthen her presence in her colonies, started putting the colonies on the path towards modernisation which brought about transportation system, education, communication, extensive agricultural practice and industrial scheme.

Next in rank to the above are 136 respondents standing for $77.27 \%$ and 49 respondents representing $22.72 \%$ respectively strongly agreed and agreed that it is not only the culture of the Western world that influences Africans, but also that of the Eastern culture too. This is in conformity with the finding of Oderinde et al. (2012) who opine that indeed it is not only the culture of the West but also that of the Eastern society that are prominently seen in Nigeria today.

Close in rank to the above finding are 123 respondents representing $69.89 \%$ and 41 respondents representing $23.30 \%$ who respectively strongly agreed and agreed that not much authority is accorded our traditional rulers (Emirs, Obas and Obis). Adalumo A. J. and Adalumo C. (1999) affirm that respect for elders and constituted authorities were known to be much valued in the traditional Nigerian society. The children had to prostrate (for boys) or kneel down (for girls) while greeting their elders, these aided peaceful co-existence among the Africans based on communalism and common respect, while only 9 respondents representing $5.11 \%$ and 3 respondents standing for $1.70 \%$ respectively disagreed and strongly disagreed.

In a similar vein, 111 respondents representing $63.07 \%$ and 57 respondents representing $32.39 \%$ respectively strongly agreed and agreed that traditional African religions have been over taken by the European religion. The finding connotes the study of Bello (2011) that Christianity, like Islam is an alien religion in Africa. It was introduced to the African continent by the White Missionaries from the Western part of the world (Europe and America). The Portuguese's Missionaries took the lead, and in 
no distance time were followed by other missionaries from countries like Britain, Holland, Spain, Germany, Belgium, France and America.

\section{Conclusion}

Considering the over-shadowing-influence of the English language in the British controlled colonies up to date, one would philosophise that of all the heritages left behind in the British colonies by the British overlords, probably, none is more important than the English language, and it is indeed very likely for sometime to come, English language will remain a vital access to global advances which is very essential for any developing nation because it has been seen as the tool for gaining access to science and technology. With these, it is then possible that the Anglophone countries would grind to a halt should the use of English be outlawed for five minutes, and possibly the whole world. It is therefore concluded that the English language has got both positive and negative impacts on Nigeria and Nigerians having seen highest respondents in these directions.

\subsection{Recommendation}

Based on the findings and the conclusion, it is therefore recommended that Africans, especially Nigeria cannot be an island to itself, and if it must have any global outlook it must embrace foreign influence and culture so that Africans as a whole and indeed Nigerians would fit into any global condition regardless of their cultural background.

\section{References}

Adalumo, A. J., \& Adalumo, C. (2016). The Sweet bed unidentified and the Joy of Marital Love. Ilorin: World Missionary Publishers.

Bello, Y. (2011). Students Personality Traits and Performance Correlates of High Grades in Senior School Certificate in Kwara State, Nigeria (An unpublished Ph. D Thesis). University of Ilorin, Ilorin, Kwara State.

Bello, Y. K. (2006). An analysis of oral reading and comprehension performance of Junior Secondary School Students. Offa Kwara State, Nigeria Unpublished M.Ed. Project University of Ilorin, Ilorin, Nigeria.

Fafunwa, A. B. (2006). New Perspective in African Education. London and Bakingstoke: Macmillan Education Ltd.

Meduewesi, E. J. (2000). A paper written as an introduction to the national values curriculum of Nigeria, Abuja, Nigeria Education Research and Development Council.

Oderinde, D. B. (2009). Introduction to Moral and Religious Education. Ilorin: Sir Kay Publisher.

Oderinde, D. B., \& Bello, Y. K. (2012). Perception of Kwara State Youths on the Need for cultural studies in Nigeria. Nigerian Journal of Social Studies, XV(2).

Omoniyi, J. (2004). Lecture notes on Oral Literature and its National Importance. 